[This is a pre-print version of the introduction for the Theme Issue on 'Labov and sociolinguistics: Fifty years of language in social context' in Journal of Sociolinguistics (2016, Vol. 20, Issue 4). Please consult the final version if citing: http://onlinelibrary.wiley.com/doi/10.1111/josl.2016.20.issue-4/issuetoc.]

\title{
Labov in Sociolinguistics: An Introduction
}

\author{
Allan Bell, Auckland University of Technology \\ Devyani Sharma, Queen Mary University of London \\ David Britain, University of Bern
}

\begin{abstract}
This theme issue marks fifty years since the publication of William Labov's Social Stratification of English in New York City, the foundation study of variationist sociolinguistics. In this Introduction, the editors offer their rationale for the shape of the theme issue. We briefly survey the innovations and impact of the New York study, together with the subsequent development of the field by Labov and others. We then touch on several strands of Labov's contribution to sociolinguistics: language change, linguistic evaluation, methodological innovation, African American English, language and the individual, and language style. We conclude with a reflection on Labov's commitment to the study of language in society.
\end{abstract}

Keywords: Labov, New York City English, variationist sociolinguistics, language change, sociolinguistic methodology, style.

2016 marks fifty years since the publication of William Labov's Social Stratification of English in New York City (1966) - his doctoral thesis, the foundation study of variationist sociolinguistics, and a milestone in the development of the field of sociolinguistics. The editorial team of the Journal of Sociolinguistics has taken this anniversary as an occasion to bring together a theme issue which overviews and evaluates the contribution Labov has made to the field of sociolinguistics - not just through the New York study but across more than half a century of innovative research.

Our contributors were given the challenge of working in an unusual genre: overviewing and assessing a single scholar's work, and doing so informatively, evaluatively and clearly. The essays set out to convey to readers - including students the essence of research enquiry in each area of Labov's work, and also to capture some of the colour and flair of what he has done. Their aim is to clarify why Labov's contribution to these areas has mattered. How and why has it inspired some people? How and why has it provoked others? What has been the uptake in linguistics? How has it been built on? What may have proved unsatisfactory or misleading? What was its influence beyond sociolinguistics? What - amongst all this - is Labov's contribution to a future sociolinguistics? What paths does it open up? The articles also give a sense not just of Labov's own work but, more generally, of the Labovian paradigm and its impact. 
Contributors have been asked to evaluate and not just describe, including potentially to critique if they believe there are gaps or problems in Labov's approach. This theme issue, then, is not intended as a festschrift. There can be no doubt that much of the contents add up to a confirmation of what Labov has contributed to our field, but that affirmation is made with a clear-eyed awareness of possible limitations and drawbacks as well as of achievements.

We editors have tried to ensure comprehensive coverage of the main strands of Labov's work, although not all to the same depth. It was a challenge trying to divide up his work for this kind of coverage, and obviously there are alternative ways to cut the cake. As well as this Introduction and Labov's own discerning Afterword, there are nine substantive essays. Six of those are longer articles which cover what we identified as the major areas of Labov's contribution: sociolinguistic change and theory (Coupland), linguistic theory (Cornips \& Gregersen), sound change (Kiparsky), methodology (Meyerhoff), narrative (Johnstone), equity and African American English (Rickford). Three shorter pieces cover important dimensions of Labov's work which could not be adequately corralled in the longer papers: Gal on Labov and anthropology, Thomas on the Atlas of North American English, and Stanford on Labovian research beyond English. Labov's Afterword comments on the contents of the issue as a whole, article by article - each of its sections can usefully be read in conjunction with the paper that it deals with. As well as our debt to the contributors and to William Labov himself, we owe particular thanks to Walt Wolfram, who has brought all his experience - nearly as long as Labov's own - to the task of reviewing the full suite of essays.

\section{Researching English in 1960s New York}

Labov's New York work is arguably the most influential single study in sociolinguistics. To summarize its well-known story: Labov began his doctoral project on the Lower East Side of Manhattan in 1962, aiming to map the social distribution of the English of New York and to identify how it was changing. A total of 122 speakers were eventually interviewed, mostly by Labov himself. The interviews included questions on language background, word and concept definitions, childhood games, pronunciation tasks, and language perceptions and attitudes. Labov concentrated particularly on eliciting five different 'styles', especially 'casual speech'.

Analysis of these speakers' language involved an innovative construct that remains still at the heart of the variationist enterprise - the (socio)linguistic variable. A variable offers speakers the choice between two (or more) alternative linguistic forms which have 'the same (denotative) meaning' but different social significances. The scope of the variable is defined strictly, the occurrences of each variant are counted, and the ratio of actual in relation to potential occurrences of each form is calculated. Fifty years on, it is easy to forget how revolutionary and enabling this one breakthrough has been (see the discussion in Cornips \& Gregersen's essay). The resulting variability was demonstrated in what became iconic line graphs plotting the stratification of class against style, a format on which countless displays in hundreds of studies have subsequently been patterned. The displays present the measurement of language variability in a luminously unmissable way: these graphs talk. Overall, the doctoral 
study, which eventually provided most of the content of Labov's 1972 book, Sociolinguistic Patterns, was pioneering on many fronts:

- the conception and design of the project and sample - urban, random, comprehensive

- the methodology of the sociolinguistic interview for eliciting different styles, especially casual speech

- the construct of the (socio)linguistic variable, and the discovery of systematic social and stylistic structure in language

- the analytical method for quantifying linguistic variation, correlating it with social difference, and identifying language change in progress

- establishing that the same linguistic variable serves to signal both social and style stratification. In Labov's lucid phrase, 'it may therefore be difficult to interpret any signal by itself - to distinguish, for example a casual salesman from a careful pipefitter' (1972b: 240).

The last statement points to the perils of interpreting quantitative data, since correlation does not equal causation let alone an explanation - lessons which variation researchers still re-learn today. Subsequent scholars have also noted that the structural-functionalist social paradigm which Labov adopted, the default approach in the 1960s, implies a consensus, status-quo view of social class (Rickford 1986, Milroy \& Milroy 1992). They suggest that a conflict model may be more appropriate, at least in some circumstances, and that it might sit more comfortably with Labov's long commitment and contribution to social equity.

\section{Beyond and after New York}

Other researchers quickly adopted Labov's approach - Shuy, Wolfram \& Riley (1968) followed soon after in Detroit (see also Wolfram 1969), then in the U.K. came Trudgill's $\mathrm{PhD}$ on the social differentiation of English in Norwich (published in 1974). Variation research on a Romance language was initiated by a project with a large random sample of Montreal French conducted by Cedergren, D. Sankoff and G. Sankoff (Sankoff \& Sankoff 1973). From the 1970s the variationist approach quickly became dominant in North America (where there has indeed been some tendency to equate it with sociolinguistics as a whole). With its own annual conference, NWAV (New Ways of Analyzing Variation) and journal, Language Variation $\mathcal{E}$ Change, variationism has arguably become, as Meyerhoff notes in her essay, a broad Community of Practice, particularly in North America.

There has been a substantial body of variationist work on the Romance languages - French, Spanish and Portuguese (especially in the Americas). A scan of recent issues of Language Variation and Change shows articles on more than a dozen other languages including Arabic, Dutch, Russian, Cantonese, Guaraní, Old Norse, Korean, Māori and Australian Sign Language. Stanford's article in this issue discusses the influence of Labovian variationism on the study of languages other than English, especially 'small' languages in non-Western contexts. Nevertheless, the predominant work in the paradigm remains on English, plus the Romance languages. It seems possible that the Western, specifically American, origins of variationism may have 
militated against uptake in some other contexts. Perhaps the methods of the New York study and its successors were regarded as fitted to an American form of class stratification rather than to other modes of social organisation. Coupland's essay considers whether perceived shifts in social class in Western societies since the 1960s affect the applicability of Labov's approach. It is also interesting to contemplate why the application of variationist methods to change in Romance languages has been so much greater in the Americas than in Europe.

The New York study originated against the uncompromising background of the hegemonic transformational theory of the time, which effectively sidelined the use of naturally-occurring data in linguistics. Despite Labov's criticism of Chomskyan methods, he situated his work in the tradition of generative grammar, and our contributors take different views on how this positioning has played out (Kiparsky, Cornips \& Gregersen).

But Labov's innovations did not occur in isolation: a broad swathe of sociolinguistic research was establishing itself across North America. The framing and contents of the founding collections which appeared around this time (e.g. Hymes 1964, Fishman 1968, 1972; Gumperz \& Hymes 1972) make it clear that there was a rich, stimulating and diverse commonality of interest and exchange in which Labov's own pioneering work was embedded. The 1964 Sociolinguistics Conference at UCLA - one of the formational meetings of North American sociolinguistics - brought together many whom we know today as the founders of the field, including Labov (the proceedings were published in Bright 1966). Fishman's 1968 collection entitled Readings in the Sociology of Language carried a chapter by Labov on the New York City study, but also ranged across contributions by Lambert, Lieberson, Jakobson, Haugen, Bernstein, Ferguson, Hymes, Gumperz and many others - well beyond what would now be regarded as the 'sociology of language' paradigm.

Nevertheless, Labov with his New York City study was the unique founder of variationist sociolinguistics, and the core of this approach has remained remarkably stable since. The proceedings of the first Conference on New Ways of Analyzing Variation in English bore this dedication: 'To William Labov, who freed us from static analysis' (Bailey \& Shuy 1973). He has also remained the field's leading figure. As Trudgill writes in his Editor's Preface to Labov (1994: ix):

Having been the originator of this way of doing linguistics ... Labov has for thirty years remained at its very forefront and has continued to be not only its senior and most influential practitioner but also its best.

\section{Strands of Labov's contribution}

Linguistic change, rather than just variation, has been the leading focus of Labov's work, reflected in his three-volume Principles of Linguistic Change (1994, 2001, 2010). The New York City study provided most of the empirical illustrations for the joint Weinreich, Labov \& Herzog (1968) article which laid the foundations for Labov's lifelong work on sound change. They stressed that, in contrast to the prevailing theories, language does not have to be homogeneous to be orderly and structured, identifying five problems for a theory of language change: constraints on change, transition stages, social and linguistic embedding, evaluation and actuation of change. 
Labov's trilogy returns to these original issues throughout. An important outcome of a focus on sound change, as well as of Labov's debt to and transformation of traditional dialectology, is the Atlas of North American English (Labov, Ash \& Boberg 2006), discussed in Thomas's article in this issue. From the standpoint of general linguistics, Kiparsky's paper presents a view on Labov's contribution to the understanding of sound change. Nevertheless, the conclusion of Cornips \& Gregersen's essay would seem to be that general theoretical linguistics has largely overlooked Labov's work (along with other sociolinguistic contributions).

One area which would have merited its own essay is Labov's research on linguistic evaluation (although it does receive some coverage in Meyerhoff's essay). While work on attitudes towards languages as 'wholes' was being pioneered at the same time in Montreal (Lambert's matched guise technique, e.g. 1967), the New York City project initiated the study of listeners' evaluations of individual sociolinguistic variables. As well as recording his informants' language production, Labov tested their perceptions by playing them recordings of other New York speakers and asking them to rank the speakers. The findings were a surprise: the more that informants produced a stigmatized feature in their own speech, the more sensitive they were to hearing it. Labov has continued this attitudinal work (e.g. Labov et al. 2011), and it is pursued with increasingly sophisticated methods by the present generation of scholars (e.g. Campbell-Kibler 2008, Squires 2013).

A feature of Labov's work from the New York study onwards has been methodological innovation and triangulation, especially in fieldwork, as described in Meyerhoff's essay. All sociolinguists know where and why Labov was looking for the 'fourth floor', with its phono-opportunities for production of the (r) variable. This pilot for the New York study sampled 274 speakers in a day's work through a 'rapid and anonymous' survey of department store staff who responded to his questioning about goods on the fourth floor. The study, complementary in design to the main survey project, produced similarly stratified findings.

Again, in the decades-long series of studies Labov and his collaborators have conducted in Philadelphia, they have tested speakers' ability to hear a vowel distinction they cannot produce - a 'near merger' - in words like merry and Murray. The so-called 'coach test' involved a story about a baseball game where the coach faced a choice between a boy named Murray and a girl nicknamed Merion. Which name the subjects think they are hearing in the coach's decision indicates their perception of the near-merged vowels. But Labov knows that academic expertise in mergers does not necessarily rescue linguists from misunderstanding other speakers. He records his own and others' confusion (1994: 326) over copy and coffee as a result of the low back vowel merger (and wrily notes the tendency of these two words to co-occur in academic discourse):

D. Sankoff: It's time to make the copies.

W. Labov: But I've already had my coffee.

Labov has also promoted and practised enhanced statistical processes and modelling in the field's quantitative methods. From a beginning in the New York study, where differences in raw descriptive statistics were deemed not to need statistical tests, he has led and encouraged increasing sophistication of statistical procedures - from the 
variable rule, through the Varbrul programme developed by D. Sankoff (Cedergren \& Sankoff 1974), to R (Johnson 2009) and beyond. ${ }^{1}$ And the development of forced alignment and vowel extraction (Rosenfelder et al. 2011) at Labov's laboratory is now leading variationists into the era of big data.

Although the New York study sampled a range of New York's ethnicities, it was Labov's next major project that began his longterm focus on African American English, as Rickford (an ex-student) highlights in his essay. It was an innovative ethnographic study of New York adolescent street clubs, drawing on the tradition of work that Gumperz was establishing (see Gal's essay). Two White linguists collaborated with two local Black field workers, and the academic and social outcomes were significant, published in Labov et al. (1968): a description of Black youth speech events and rhetorical styles; study of the structure of conversational stories (see Johnstone's essay in this issue); and, most sociopolitically significant, the conclusion that inner-city ethnic vernaculars were not substandard linguistic codes, but had their own systematicity - 'the logic of non-standard English', as Labov's title ran (1972a).

This work seeded scores of studies and thousands of publications, so that we now know more about African American English than any other non-mainstream variety. Its features have been comprehensively analyzed and quantified on a wide range of socio-demographic dimensions - regional differences throughout the U.S., isolated relict communities, individual case studies of young and old, contrasts between women and men, between middle and working class, and the developmental paths of African American children. Since the 1970s successive generations of African American sociolinguists have taken the lead in much of this research, many of them Labov's students. The essays by Gal and Rickford note Labov's commitment to supporting the African American community through advocacy and educational resources such as literacy programmes. And we can note the dedication in Language in the Inner City (1972a), the book derived from the adolescent street clubs project: 'To the Jets, the Cobras, and the Thunderbirds who took on all odds and were dealt all low cards'.

An aspect of Labov's practice that has not always played out in the work of his successors is an ethnography-like focus on the language of the individual. This began in the New York study with the deviant case of Nathan B., an upper-middle-class man of academic prowess who could not pronounce his fricatives. His 'lower-class' pronunciations of dese for 'these' and dose for 'those' (Labov 2006: 158) terminated an academic career. Labov's courtroom analysis of another individual, Paul Prinzivalli, is now seen as a classic case in forensic and applied linguistics. As with his work on African American English, Labov (1997) saw this as a crucial test of the usefulness of his work:

It was almost as if my entire career had been shaped to make the most effective testimony on this one case... By means of linguistic evidence, one man could be freed from the corporate enemies who had assailed him, and another could sleep soundly on the conviction that he had made a just decision.

Labov has also profiled those individuals he identifies as linguistic innovators. Among these is Celeste S. (Labov 2001), the hub who links different groups on 'Clark' St in South Philadelphia. For the two big new changes in the Philadelphia vowel system - 
the MOUTH and FACE diphthongs - Celeste is leader in her generation, one of a handful of women whose sociolinguistic distinction displays both their history of nonconformity and upward mobility. Labov (2009) highlights six such individuals who have particularly affected him in a lifetime of fieldwork - and their stories are told with the clarity and colour that has characterized his writing style. This succession of drawing striking sociolinguistic portraits is continued in the work of Eckert, a former student. Her ethnography of a Detroit high school (2000) profiles Judy, the burned-out burnout who wears dark eyeliner, tight jeans and fringed rawhide boots - and leads the field in tensing front vowels.

The same ear for the human voice in language has led Labov to a continuing interest in narratives, especially life-and-death stories. Johnstone's essay shows how influential his narrative-analysis framework has been, reaching well beyond sociolinguistics and other language-focused fields to areas as diverse as clinical psychology and media studies.

Of all the areas his work has addressed, Labov's handling of style - originally in the 1966 study but also subsequently - has possibly incurred the most scrutiny (see the essays by Gal and by Coupland, especially concerning 'the vernacular'). Fifty years on, the study of style has broadened and deepened well beyond attention-to-speech as an explanation, and has moved to centre-stage in sociolinguistic thinking. But it retains its debt to the foundations Labov laid in New York City, for example in the tripartite division of sociolinguistic variables into indicators, markers and stereotypes. It is worth noting, as an example of Labov's openness to challenge, that he was instrumental in bringing Bell's Audience Design article (1984) - which included critique of his approach - into publication in Language in Society.

\section{Conclusion: where language meets society}

A quirk of Labov's positioning in the 1960s and 1970s was that he queried the label 'sociolinguistics' in his introduction to what was one of the first books with the term in its title - 'since it implies that there can be a successful linguistic theory or practice that is not social' (1972b: xiii). His earlier preface to the New York study merits careful reconsideration fifty years on:

... sociolinguistics is more frequently used to suggest a new interdisciplinary field - the comprehensive description of the relations of language and society. This seems to me an unfortunate notion, foreshadowing a long series of purely descriptive studies with little bearing on the central theoretical problems of linguistics or of sociology. My own intention was to solve linguistic problems, bearing in mind that these are ultimately problems in the analysis of social behaviour.

Labov 2006 [1966]: viii

Although Labov makes it clear that his own focus is on linguistic issues, there is an implicature in the quotation which indicates a converse: an appropriate sociolinguistics will also legitimately deal with issues in social theory. It will avoid just describing, and will not be atheoretical on its social dimension any more than on the linguistic. The danger of being 'just descriptive' remains always with us - perhaps 
even more sharply in the $21^{\text {st }}$ century, where the term 'sociolinguistics' has broadened to cover such a wide range of enquiry.

J. Milroy (1992) cites Labov as stating that the nature of linguistic data can make linguistics the most exact of the social sciences. The capturability of language also makes the material that we study arguably the most usable data available through which to examine many sociotheoretical issues. A sociolinguistics that is at once both thoroughly linguistic and thoroughly social, celebrating the profusion of language and its speakers, and applying its knowledge in the cause of social equity, is a worthy outcome of Labov's contribution to the field, from the New York study onwards.

\section{References}

Bailey, Charles-James N. \& Roger W. Shuy (eds), 1973. New Ways of Analyzing Variation in English. Washington, D.C.: Georgetown University Press.

Bell, Allan, 1984. 'Language style as audience design.' Language in Society 13: 145-204.

Bright, William (ed.), 1966. Sociolinguistics. The Hague: Mouton.

Campbell-Kibler, Kathryn, 2008. 'I'll be the judge of that: diversity in social perceptions of (ING). Language in Society 37: 637-59.

Cedergren, Henrietta \& David Sankoff, 1974. 'Variable rules: Performance as a statistical reflection of competence.' Language 50: 333-355.

Eckert, Penelope, 2000. Linguistic Variation as Social Practice: The Linguistic Construction of Identity in Belten High. Malden, Mass.: Blackwell Publishers.

Fishman, Joshua A. (ed.), 1968. Readings in the Sociology of Language. The Hague: Mouton.

Fishman, Joshua A. (ed.), 1972. Advances in the Sociology of Language (Vol. 2). The Hague: Mouton.

Gumperz, John J. \& Dell Hymes (eds), 1972. Directions in Sociolinguistics. New York: Holt, Rinehart \& Winston.

Hymes, Dell (ed.), 1964. Language in Culture and Society: A Reader in Linguistics and Anthropology. New York: Harper \& Row.

Johnson, Daniel Ezra, 2009. 'Getting off the GoldVarb standard: Introducing Rbrul for mixedeffects variable rule analysis.' Language and Linguistics Compass 3: 359-83.

Labov, William, 1966. The Social Stratification of English in New York City. Washington, D.C.: Center for Applied Linguistics.

Labov, William, 1972a. Language in the Inner City: Studies in the Black English Vernacular. Philadelphia: University of Pennsylvania Press.

Labov, William, 1972b. Sociolinguistic Patterns. Philadelphia: University of Pennsylvania Press.

Labov, William, 1994. Principles of Linguistic Change, Volume 1: Internal Factors. Cambridge, Mass.: Blackwell Publishers.

Labov, William. 1997. 'How I got into linguistics, and what I got out of it.' http://www.ling.upenn.edu/ wlabov/HowIgot.html

Labov, William, 2001. Principles of Linguistic Change, Volume 2: Social Factors. Malden, Mass.: Blackwell Publishers.

Labov, William, 2006. The Social Stratification of English in New York City (2nd ed.). Cambridge: Cambridge University Press.

Labov, William. 2009. 'A Life of Learning: Six People I Have Learned From.' https://www.acls.org/publications/audio/labov/default.aspx?id=4462

Labov, William, 2010. Principles of Linguistic Change, Volume 3: Cognitive and Cultural Factors. Malden, Mass.: Wiley-Blackwell.

Labov, William, Sharon Ash \& Charles Boberg, 2006. The Atlas of North American English: Phonetics, Phonology and Sound Change. Berlin: Mouton de Gruyter. 
Labov, William, Sharon Ash, Maya Ravindranath, Tracey Weldon, Maciej Baranowski \& Naomi Nagy, 2011. 'Properties of the sociolinguistic monitor.' Journal of Sociolinguistics 15: 431-63. Labov, William, Paul Cohen, Clarence Robins \& John Lewis, 1968. A Study of the Non-standard English of Negro and Puerto Rican Speakers in New York City. Washington, D.C.: Educational Resources Information Center.

Lambert, Wallace E., 1967. 'A social psychology of bilingualism.' Journal of Social Issues 23: 91109.

Milroy, James, 1992. 'The theoretical status of sociolinguistics.' In Kingsley Bolton \& Helen Kwok (eds), Sociolinguistics Today: International Perspectives. London \& New York: Routledge. 356-60.

Milroy, Lesley \& James Milroy, 1992. 'Social network and social class: toward an integrated sociolinguistic model.' Language in Society 21: 1-26.

Rickford, John R., 1986. 'The need for new approaches to social class analysis in sociolinguistics.' Language \& Communication 6: 215-221.

Rosenfelder, Ingrid; Fruehwald, Joe; Evanini, Keelan and Jiahong Yuan. 2011. FAVE (Forced Alignment and Vowel Extraction) Program Suite. http://fave.ling.upenn.edu.

Sankoff, David \& Gillian Sankoff, 1973. 'Sample survey methods and computer assisted analysis in the study of grammatical variation.' In Regna Darnell (ed.), Canadian Languages in their Social Context.

Edmonton, Alberta: Linguistic Research Inc. 7-64.

Shuy, Roger W., Walt Wolfram \& William K. Riley, 1968. A Study of Social Dialects in Detroit. Washington, D.C.: Educational Resources Information Center.

Squires, Lauren, 2013. 'It don't go both ways: Limited bidirectionality in sociolinguistic perception.' Journal of Sociolinguistics 17: 200-237.

Trudgill, Peter, 1974. The Social Differentiation of English in Norwich. London: Cambridge University Press.

Weinreich, Uriel, William Labov \& Marvin I. Herzog, 1968. ‘Empirical foundations for a theory of language change.' In W.P. Lehmann \& Yakov Malkiel (eds), Directions for Historical Linguistics: A Symposium. Austin: Texas University Press. 95-188.

Wolfram, Walter A., 1969. A Sociolinguistic Description of Detroit Negro Speech. Washington, D.C.: Center for Applied Linguistics.

\section{Notes}

1 Thanks to Walt Wolfram for this observation. 